IFN Working Paper No. 742, 2008

\title{
Does Hedonic Price Indexing Change Our Interpretation of Economic History? Evidence from Swedish Electrification
}

Harald Edquist 


\title{
Does hedonic price indexing change our interpretation of economic history? Evidence from Swedish electrification ${ }^{1}$
}

\author{
By
}

\author{
Harald Edquist
}

\author{
This paper was accepted for publication in the Economic History Review on \\ December 2, 2007. It is available on Early View since August 15, 2009: \\ http://www3.interscience.wiley.com/journal/120120169/issue
}

\begin{abstract}
Rapid price decreases for ICT-products in the 1990s have been largely attributed to the introduction of hedonic price indexes. Would hedonic price indexing also have large effects on measured price and productivity during earlier technological breakthroughs? This paper investigates the impact of hedonic and matched model methods on historical data for electric motors in Sweden 1900-35. The results show that during the productivity boom of the 1920s, current prices for electric motors decreased by 13.2 and 12.2 percent per year depending on whether hedonic or matched model price indexes were used. This indicates high productivity growth in the industry producing electric motors in 1919-29. In contrast to Sweden, the US annual total factor productivity growth was only, according to current best estimates, 3.5 percent in Electric machinery compared to 5.3 percent in manufacturing in 1919-29. However, hedonic price indexes were not used to calculate US productivity. Finally, it is shown that the price decreases for electric motors in the 1920s were not on par with the price decreases for ICT-equipment in the 1990s, even if hedonic indexing is used in both cases.
\end{abstract}

Keywords: Hedonic price index; Electric motor; Productivity growth; Electrification; ICT revolution; General Purpose Technologies; Innovation.

JEL Classification: L60; N60; O10; O14; O33; O40

\footnotetext{
${ }^{1}$ I am grateful for useful comments and suggestions from Magnus Henrekson, Jonas Ljungberg, Daniel Waldenström, Eugene White and participants at seminars at Stockholm School of Economics. Financial support from the Jan Wallander and Tom Hedelius Foundation is also gratefully acknowledged.
} 


\section{Introduction}

During the 1990s prices of ICT-products decreased rapidly, which resulted in high productivity growth for ICT-producing industries. ${ }^{2}$ In the 1990s many statistical agencies began to use hedonic price indexes to measure quality adjusted price changes in ICTproducts. This has given rise to a debate whether hedonic price indexes overstates price decreases and productivity growth. According to Triplett (2004) hedonic price indexes have been criticized for creating rapidly falling prices, resulting in overstated productivity figures for ICT-producing industries.

The ICT-revolution is an example of a major technological breakthrough. Major technological breakthroughs are based on technologies that have been named general purpose technologies (GPTs) (Bresnahan and Trajtenberg 1995). According to the GPT literature whole eras of technical progress are driven by a few GPTs, characterized by pervasiveness, inherent potential for technical improvements and innovational complementarities giving rise to increasing returns to scale. There are also other perspectives and theoretical approaches to analyze major technological breakthroughs. ${ }^{3}$ However, no matter which perspective that is being used, one of the most crucial issues about technological breakthroughs is the ability to correctly measure their impact.

One of the main indicators for measuring the impact of new technology is productivity. In order to measure productivity correctly over time it is necessary to estimate the price change of different products. ${ }^{4}$ One of the major difficulties with measuring prices in industries with rapidly changing technologies is the problem of correctly estimating quality improvements. In order to deal with this problem many statistical agencies use the so called "matched model" methodology to adjust for quality changes in price indexes. Another way of taking quality improvement into account is to use a hedonic price index. ${ }^{5}$ The hedonic methodology is used extensively for ICT-products in the US, while European countries have been slower in adopting hedonic methods (van Mulligen 2003).

Previous GPTs are, for example, the steam engine, the combustion engine and electrification. However, ICT is the only GPT where hedonic price indexes have been used systematically to estimate quality adjusted price changes. An important question is how matched model and hedonic price indexes would affect prices for products that were crucial for previous GPTs? This paper investigates the impact of different price indexes on electrification, which was the GPT preceding the ICT-revolution. The analysis focuses on the effects on the electric motor, which was crucial for the electrification in manufacturing.

\footnotetext{
${ }^{2}$ OECD (2002) defines the following industries as ICT producing: Office accounting and computing machinery (ISIC 30), Insulated wire and cable (ISIC 313), Radio, television and communication equipment (ISIC 32), Instruments and appliances for measuring, checking, testing, navigating and other purposes, except industrial process control equipment (ISIC 3312), Industrial process control equipment (ISIC 3313), Wholesale of machinery, equipment and supplies (ISIC 5150), Renting of office machinery and equipment (ISIC 7123), Telecommunications (ISIC 642) and Computer and related services (ISIC 72).

${ }^{3}$ See for example Freeman and Soete (1987).

${ }^{4}$ The change in prices is used to calculate value added and production value in constant prices, which are used to calculate labor and total factor productivity.

${ }^{5}$ For definitions and a detailed discussion of hedonic and matched model methodology see sections 3.1 and 3.2 .
} 
It is well known that the electric motor changed the production process in many different industries (Devine 1983). Moreover, there is a correlation between the change in electric motor capacity and the change in productivity growth in different US industries 1919-29 (David 1990, 1991). However, total factor productivity (TFP) growth did not increase more than 3.5 percent per year in US Electric machinery. This was clearly below the average annual TFP growth of 5.3 percent in US manufacturing in 1919-29. ${ }^{6}$ Unlike the US experience of the 1920s, the productivity growth during the 1990s was very high for ICT-producing industries in the US and many western European countries. Thus, during electrification the highest productivity growth was found in industries using electric motors, while during the ICT-revolution of the 1990s the highest productivity growth was observed in industries producing ICT (Edquist \& Henrekson 2004).

The question stated above is very broad. More specifically I will address the following questions:

(i) Do hedonic price and matched model price indexes change the view of the productivity performance in the industry producing electric motors?

(ii) Do price changes differ for electric motors depending on whether the matched model or the hedonic methodology is used?

(iii) Can the price changes for electric motors during the 1920s rival the price change of computers and other ICT-products during the 1990s?

To answer these questions I construct hedonic and matched model price indexes for electric motors in Sweden 1900-35.

\section{Electrification and the ICT-revolution}

\subsection{Electrification}

The invention of the dynamo was crucial for the $19^{\text {th }}$ century electric industry. The principle behind the dynamo - the theory of electromagnetic induction - was discovered by Michael Faraday in 1831. However, the first commercial power station did not start to operate until the 1880s in the US and many European countries. It was also around 1880 that the first electric motors, based on electromagnetic induction, began to be produced commercially. However, it took until the 1920s until productivity in manufacturing experienced higher rates of productivity growth (David 1991).

David (1991) argues that electrification paved the way for a thorough rationalization of factory construction designs and internal layouts of production. One such rationalization was the shift from shafts to wires in the production system (Devine 1983). Before electricity was introduced, the production process was built around a large-scale power

\footnotetext{
${ }^{6}$ Annual labor productivity growth, defined as value added per person employed, was 5.1 percent in US manufacturing and 4.1 percent in Electric machinery in 1919-29. Productivity estimates are based on Kendrick (1961).
} 
source, such as a waterwheel or a steam engine. The first electric motors used in production just replaced steam engines and continued to turn long line shafts. However, it was soon discovered that large energy savings could be realized if a group of machines were driven from a short line shaft turned by its own electric motor. A further step was to connect a single electric motor to each machine. This unit drive innovation used less energy than the line shaft drive and it also increased the flexibility of the production process. In this way the unit drive offered an opportunity to obtain greater output per unit of inputs (Devine 1983). However, it took a long time until factories had been reorganized to take full advantage of the productivity effects of the electric motor.

Table 1 presents data from Kendrick (1961) on labor- and total factor productivity growth in different manufacturing industries in the US. According to these estimates a substantial productivity increase did not appear in the industry producing Electric machinery. For the period 1919-29 annual TFP growth in US manufacturing was 5.3 percent, while TFP growth in Electric machinery was only 3.5 percent per year. The change in TFP growth from 1909-19 to 1919-29 for manufacturing and Electric machinery is 5.0 and 3.2 percentage points, respectively. The labor productivity growth in Electric machinery was 4.1 percent compared to 5.1 percent in manufacturing. David (1991) shows that there is a correlation between the change in the rate of industry productivity growth from 1909-19 to 1919-29 and the ratio of secondary electric motor capacity in each industry in 1929 to that capacity in 1919. Hence, the productivity effects were materialized in sectors using electric motors rather than in sectors producing it. This suggests that the industry actually producing the electric equipment was not able to take advantage of its own technology to the same extent as other industries.

When it comes to productivity growth in Sweden it appears that Sweden followed the US pattern. Schön (2000) shows that labor productivity growth in Swedish manufacturing increased from 1.5 percent p.a. in 1896-1910 to 2.9 percent in 1910-35. ${ }^{7}$ Table 2 shows labor productivity growth for different industries in the Swedish manufacturing and handicraft sector 1913-46. As in the US, productivity growth accelerated in the period 1919-29. Chemicals and chemical products and Power, lightening and waterworks experienced the highest rates of productivity growth in 1919-29. In the Swedish industry classification system Electric machinery was included in the Ore- Mining and Metal industry. This industry had an annual labor productivity of 4.3 percent compared to 3.8 percent for total manufacturing and handicraft. It has not been possible to obtain estimates of labor productivity defined as value added per unit of labor for Electric machinery $1913-46 .^{8}$

\subsection{The ICT-revolution}

In 1947 Bardeen, Brattain and Shockley invented the transistor. The transistor became the basis for numerous electronic innovations. Together these innovations formed what is called the Information and Communications Technology (ICT) sector. The development of numerous innovative technologies has given rise to a plethora of new products providing the basis for development within the ICT sector. Communication satellites in

\footnotetext{
${ }^{7}$ Schön (2000) defines labor productivity as growth rates of real value added per hour worked.

${ }^{8}$ For productivity growth estimates for Electric machinery, based on production value instead of value added, see section 6.1 .
} 
the 1960s, fiber optic cables in the 1970s and cellular telephones first introduced during the 1980s are significant examples of such product innovations. The Internet is yet another innovation that is believed by many to be a crucial driver of economic growth (Litan \& Rivlin 2001 and Lipsey et al. 1998).

Table 3 shows the labor productivity growth for different industry categories for the US and the EU in 1990-2000. According to table 3 the highest productivity growth by far was found in the ICT-producing industries for these countries in the 1990s. The annual labor productivity growth in ICT-producing manufacturing in 1995-2000 was 23.7 percent in the US and 13.8 percent in the EU compared to 2.5 and 1.4 percent for the total economies. These results clearly indicate that the highest productivity growth in these countries took place in the ICT-producing industry. Moreover, intensive ICT using service industries increased considerably more in the US compared to the EU 1995$2000 .^{9}$

\subsection{Electrification and ICT: A comparison of productivity growth}

As stated in the introduction electrification and ICT are general purpose technologies. ${ }^{10} \mathrm{~A}$ number of articles have shown that there are similarities in the productivity patterns after major technological breakthroughs. ${ }^{11}$ One such similarity is that it takes long from the time of the original invention until a substantial increase in the rate of productivity growth can be observed. ${ }^{12}$ However, one major difference between electrification and the ICT-revolution is that productivity during the 1990 s started to increase considerably more in industries producing the new technology, while productivity did not increase substantially in the industry producing Electric machinery in the US during the 1920s. Moreover, electricity in the US was adopted by all sectors at approximately the same time, whereas ICT diffused rapidly in some sectors and not-so-rapidly in others (Jovanovic \& Rousseau 2005). Moreover, Gordon (2000) argues that the productivity revival in the US occurred primarily within durable manufacturing and that there is no evidence of increases in productivity growth outside durable manufacturing.

Another difference between the productivity booms of the 1920s and the 1990s is that productivity is measured differently. Hedonic price indexes are used for ICT-products in the US and many European countries such as Sweden and France (Scarpetta et al. 2000). However, hedonic price indexes were not used by Kendrick (1961) to take quality change

\footnotetext{
${ }^{9}$ According to van Ark et al. (2002) the major difference in labor productivity between the EU and the US is due to productivity differences in the intensive ICT-using service sector because it accounts for a much larger share of the total economies compared to ICT-producing industries.

10 According to Bresnahan \& Trajtenberg (1995) GPTs are characterized by pervasiveness, inherent potential for technical improvements and innovational complementarities giving rise to increasing returns to scale. More specifically, Lipsey, Bekar and Carlaw (1998) maintain that a GPT has the following four characteristics: (i) wide scope for improvement and elaboration; (ii) applicability across a broad range of uses; (iii) potential usefulness in a wide range of products and processes and (iv) strong complementarities with existing or potential new technologies.

${ }^{11}$ See for example David (1991) and Crafts (2002).

${ }^{12}$ According to David (1991) electricity was produced commercially in the $1880 \mathrm{~s}$, but productivity started to increase in manufacturing first in the 1920s. Moreover, Crafts (2004) shows that steam power contributed little to economic growth before 1830 and had its peak impact about a hundred years after James Watt's steam engine was invented.
} 
into account. Kendrick was well aware that changes in quality would affect productivity in some industries such as Electric machinery:

\begin{abstract}
"Here, it should be noted that quality change will be greater in some industries than in others. Thus, manufactured goods are more susceptible to quality improvements than are farm products; and within manufacturing the quality improvements of automobiles and machinery, for example, has probably improved more than that of lumber and lumber products. This should be kept in mind in interpreting relative changes in output and productivity by industry." (Kendrick 1961 p. 43)
\end{abstract}

In order to investigate if the use of hedonic price indexes would result in large price changes for electric equipment, I have collected data on prices and characteristics for standardized electric motors in Sweden $1900-35 .{ }^{13}$ These data were used to construct hedonic and matched model price indexes for electric motors in Sweden.

\title{
3. Method
}

\subsection{The hedonic methodology}

Triplett (2004) defines the hedonic price index as any price index that makes use of a hedonic function. A hedonic function is a relation between the prices of different product models, such as the various models of personal computers, and the quantities of characteristics in them. As the definition indicates, hedonic price indexes may be computed in a number of ways. Here the time dummy variable method is used. This method is the most common in research, but a number of alternative methods exist. ${ }^{14}$

According to van Mulligen (2003) the hedonic method was pioneered by Waugh (1928) and Court (1939) and first applied in economic analysis by Griliches (1961). Court and Griliches, like many others, used the hedonic method to construct a price index of the automobile industry. ${ }^{15}$ For electric motors, the hedonic method has been used very little. Ljungberg (1996) constructs hedonic price indexes for electric motors in Germany and the UK. For Sweden Ljungberg uses a matched model price index. To my knowledge, no one has used the hedonic method on electric motors in Sweden and no one has compared a hedonic index with a matched model index for electric motors for any country.

\subsubsection{The time dummy variable method}

The time dummy variable method is known as a direct method since the index number is estimated directly from the regression, without other calculations. The time dummy variable method uses a time dummy variable to measure the change of prices given that

\footnotetext{
${ }^{13}$ Data have been collected for three phase alternating current slip-ring electric motors with an open construction and a frequency of 50 periods (see section 4).

${ }^{14}$ According to Triplett (2004) there are at least three other methods that can be used instead of the time dummy variable method. These are called the characteristics price index method, the hedonic imputation method and the hedonic quality adjustment method.

${ }^{15}$ See for example Raff \& Trajtenberg (1997).
} 
different price characteristics are held constant over a certain time period. To illustrate let there be $K$ characteristics of a product and let model $i$ of the product in period $t$ have the vector of characteristics $z_{i}^{t} \equiv\left[z_{i 1}^{t}, \ldots ., z_{i K}^{t}\right\rfloor$ for $i=1, \ldots I$ and $t=0, \ldots T$. Denote the price of model $i$ in period $t$ by $p_{i}^{t}$. A hedonic regression of the price of model $i$ in period $t$ on its characteristics set $z_{i}^{t}$ is given by: ${ }^{16}$

$\ln p_{i}^{t}=c_{0}+\sum_{k=1}^{K} \ln a_{k} z_{i k}^{t}+\sum_{t=1}^{T} B^{t} D^{t}+e_{i}^{t}$

where $D^{t}$ are dummy variables for the time periods, $D^{1}$ being 1 in period $t=1$, zero otherwise; $D^{2}$ being 1 in period $t=2$, zero otherwise, etc. The coefficients $B^{t}$ are estimates of hedonic price changes. The price index for year $t$ is estimated directly from the regression in equation (1) by taking the antilog of the estimated dummy coefficient $B^{t}$. The double-log functional form implies that an equally weighted geometric average of quality-adjusted relative price in two periods is estimated (see appendix A).

In equation (1) the dummy variables are used to compare prices in period 0 with prices in each subsequent period. This implies that the $a_{k}$ parameters are constrained to be constant over the period $t=0, \ldots T$. This is one of the main disadvantages with the time dummy variable method (van Mulligen 2003). However, this problem can be circumvented by pooling data only for consecutive periods. I therefore estimate the hedonic regression for two adjacent years at a time. This implies that parameters only are constrained to be constant for two adjacent years and thereby permitting a relatively unrestricted impact of changes in characteristics of prices. The estimates for each pair of adjacent years are then chained so that a price index is estimated for the whole 1900-1935 period.

\subsubsection{Selection of characteristics}

The selection of the characteristics that should be included in the regression model is one of the fundamental difficulties in hedonic studies. Selecting the right characteristics implies that one must identify the set of characteristics of electric motors that are the most important performance attributes for users. Moreover, it must be possible to measure the characteristics in a consistent fashion over time. The characteristics that are chosen should be able to go into the users' utility function. In this paper a number of technical aspects of the electric motor will be selected. However, there are also important aspects for users such as reliability that are almost impossible to quantify. According to Gordon (1990) the most serious disadvantage of all price measurement methods is that it is not possible to measure changes in the relation between excluded and included quality dimensions. The result will be a bias unless all excluded quality characteristics maintain a fixed relation with included characteristics.

The characteristics included for the electric motor are the speed determined as revolutions per minute, the power measured as horsepower and the maximum voltage measured in volts that the motor can be used for. I only include electric motors that are open slip-ring motors developed for three phase alternating current with a frequency of 50 periods (see section 4). Since this kind of motor is the most basic type among electric motors it is not

\footnotetext{
${ }^{16}$ In this paper the double-log functional form is used to estimate hedonic price indexes see section 3.1.3.
} 
necessary to distinguish between characteristics such as for example whether the electric motor is an open or closed model.

The three continuous characteristics included in the regression are listed, together with the price in price lists and are therefore believed to have played an important role for the price of electric motors in 1900-35. One characteristic that I do not include in the regression is a measure of the size of the electric motor. The primary reason for this is that most electric motors were used in factories in fixed positions. It is therefore likely that when an electric motor had been installed, its size did not matter for the production process and hence for users. Moreover, the size is closely correlated to power, which implies that much of the size effect would be picked up by the estimated coefficient of the power variable. ${ }^{17}$

One characteristic that would have been interesting to include in the regression is a measure of how efficiently electric motors use energy. ${ }^{18}$ Unfortunately, it has not been possible to find consistent measures of the energy efficiency. ${ }^{19}$ Moreover, for the years 1913-17 some motors include ball bearings while others do not. ${ }^{20}$ Therefore, a dummy variable for electric motors with ball bearings were used to test if this had any significant influence on the price. However, no significant influence could be noted from ball bearings. After 1917 ball bearings were used in almost all electric motor models.

\subsubsection{Functional form}

According to the theory of hedonic functions the form of the hedonic function is an empirical matter (Triplett 2004). Therefore, a variant of the Box-Cox test was used to determine the functional form that best fitted the data. ${ }^{21}$ The results clearly showed that the double-log form best fitted the data. Therefore, the hedonic regression was set up in the following fashion:

$\ln p_{i}^{t}=c_{0}+a_{1} \ln (\text { speed })_{i}+a_{2} \ln (\text { power })_{i}+a_{3} \ln \left(\max {\text { voltage })_{i}}+b^{t}\left(D^{t}\right)+e^{t}\right.$

where $t=\tau$ and $\tau+1, \ln p_{i}^{t}$ is the logarithm of the price for model $i$ and time period $t$, speed is measured in revolutions per minute, power measured as horsepower and maximum voltage measured in volts. $D^{\tau}$ takes the value 0 and $D^{\tau+1}$ takes the value 1.

By taking the antilog of the $b^{\mathrm{t}}$ coefficient one directly arrives at the percentage change between two different periods.

\footnotetext{
${ }^{17}$ Excluding the size of the electric motor also implies that problems with multicollinearity are avoided at the largest extent possible.

${ }^{18}$ Electric motor efficiency is the ration between the shaft output power and the electrical input.

${ }^{19}$ It has been possible to include efficiency as an explanatory variable for a few adjacent years. The results show that for the adjacent years 1900-01, 1901-02, 1902-03, 1903-04, 1904-08, 1920-21, 1925-26, 1926-28 the estimated price does not differ by more than 3 percentage points when the efficiency variable is included. However, for the period 1908-13 the difference is 7.8 percentage points.

${ }^{20}$ Before 1913 there were no electric motors in the sample of this investigation that were equipped with ball bearings.

${ }^{21}$ The test that was used for choosing between the linear and log-linear models was proposed by Pindyck \& Rubinfeld (1998). The test is based on the least squares approach (see Pindyck \& Rubinfeld (1998) pp. 278-279).
} 
where QAprice is quality adjusted price and $\% \Delta$ is percentage change. For small values of $b^{\mathrm{t}}, \% \Delta Q A$ price $\cong b^{\mathrm{t}}$, but as $b^{1}$ grows larger so does the difference between $\left(\exp \left(b^{\mathrm{t}}\right)-1\right)$ and $b^{\mathrm{t}}$.

\subsubsection{The shortcomings of hedonic price indexes}

There are several shortcomings with using the hedonic method to adjust for quality change. It is important to point out that the purpose of this paper is not to investigate the accuracy of the hedonic method. Instead, this study tries to analyze and compare the results generated by hedonic and matched model methodology for electric motors in Sweden 1900-35. Nonetheless it is important to be aware of the shortcomings with the hedonic method anyway.

One major objection towards using hedonic price indexes is that it is difficult to know what is measured. In the 1960s there used to be an erroneous perception that the coefficients from hedonic methods represented user value as opposed to resource costs. Rosen (1974) showed that hedonic coefficients generally reflect both user values and resource costs. The ratios of these coefficients may reflect consumers' marginal rates of substitution and producers' marginal rates of substitution (transformation) for characteristics. This implies that there is an identification problem in which the observed prices and quantities are jointly determined by supply and demand considerations and their underlying sources cannot be separated (ILO 2004).

A standard assumption in the theory of hedonic indexes is that there is perfect competition among firms producing the investigated product. In the case of imperfect competition, producers price their products above marginal costs which results in price mark-ups. This implies that user value is still reflected in implicit prices, but the implicit prices give no clear indication of producer costs (van Mulligen 2003). The implication of imperfect competition in the electric motor industry in Sweden is further discussed in section 6.1 .

For many types of goods it can be very difficult to identify the characteristics that are associated with price. Criticism has been raised about too much subjectivism in choosing the characteristics. However, there is no other quality adjustment method where subjectivism is not a problem. According to Triplett (2004) constructing matched models also involves subjectivism. It is also argued that theory provides little guidance to help determine the appropriate functional form of hedonic equations. However, according to Triplett this criticism is misconceived, since the choice of functional form is entirely an empirical matter.

The examples above provide a short overview of the debate about hedonic price indexes. For a more detailed investigation and discussion see Triplett (2004) and ILO (2004). 


\subsection{The matched model methodology}

In theory, the matched model is constructed by comparing exactly the same model of specific products in two time periods. ${ }^{22}$ The agency chooses a sample of sellers and product models and collects a price for the initial period for each of the models. Then, at some second period the agency collects the price for exactly the same models and sellers as in the first period. The price index is computed by matching the price for the second period with the initial period. Models that cannot be matched are excluded. In practice, it is not always exactly the same models that are being compared. The statistical agency rather specifies the size of variation in product characteristics that is acceptable for a match and thereby decides whether matching is achieved. Small changes in quality that are judged to have inconsiderable effects on the price may be ignored. A "match" is thus not necessarily an exact match.

When statistical agencies match models based on different assessments, they also introduce a quality bias. This quality bias comes in two forms: inside the sample bias and outside the sample bias. The inside type of bias occurs when prices of non-identical products are matched. The outside kind of bias occurs when the price changes of matched models are not representative of price changes of unmatched models. This bias is often strong if the share of matched models is low (van Mulligen 2003).

Here the same quality characteristics for the matched model as for the hedonic model are used, i.e. speed, power and maximum voltage. Moreover, models with ball bearings have not been matched with models with other bearings. The matched model price index was constructed by calculating the geometric mean of the price change of all the "matched" models over the two adjacent years that are compared. In order to construct a price index based on the matched model methodology for electric motors it was necessary to allow some variation of the product characteristics. Therefore, I included all matches with a variation of 0.2 horsepower, 70 revolutions per minute and 600 volts. ${ }^{23}$ If more than two models fulfilled these requirements, the two models with the closest fit were matched. When it was not possible to determine which of the models that had the closest fit, weight was used as a fourth characteristic to match models. Finally, if the weight was unknown, electric motor models produced by the same company were matched.

\footnotetext{
${ }^{22}$ It is likely that some of the models that were collected in the first period do not exist in the second period. Moreover, some models may have changed slightly over the two periods. It is then up to the agency to decide whether the slightly changed model in period 2 can be matched with the model in period 1.

${ }^{23}$ This illustrates that in order to construct matched models a number of ad hoc adjustments about different characteristics must be made. This problem is likely to have increased for ICT-products. For example, for computers there may exist over 20 different product characteristics to match.
} 


\section{The data set}

In order to construct price indexes for 1900-35, data of prices and characteristics of electric motors were collected manually from disparate sources. The data of prices and characteristics of electric motors were collected from price lists of different companies that manufactured and sold electric motors in Sweden 1900-35. The price lists were retrieved from the ASEA archives in Västerås and the Swedish Royal Library in Stockholm.

Unfortunately, it was not possible to collect prices and characteristics for every year of the period 1900-35. Therefore the calculations of hedonic and matched model price indexes are based on data for the following years: 1900-04, 1908, 1913-21, 1924-26, 1928-31, 1933 and 1935. These observations provide a good coverage of the years both before and during the productivity boom of the 1920s (see table 1 and 2). However, for the period 1900-13 the calculations of price indexes are based on observations only for a few years. Moreover, the estimated impacts of characteristics were kept constant over much longer time periods 1900-13 compared to 1913-35.

There were a number of differences among electric motor models during the period investigated. One important difference was that some electric motors were manufactured for direct current and others for alternating current. These differences make it very difficult to compute a hedonic equation that can distinguish between all different electric motor models. Therefore, this investigation only includes three phase alternating current slip-ring electric motors with an open construction and a frequency of 50 periods. The reason for making these limitations is to minimize the differences between electric motors over time. It is probable that the difference in construction and design of closed and more advanced electric motors may grow much larger over time.

The power of the electric motors included in the sample varies between 1 and 100 horsepower. Price lists indicate that there were no standardized electric motors with more than approximately 500 horsepower. ${ }^{24}$ However, price data and characteristics of electric motors with more than 100 horsepower could only be found for a few years and have therefore been excluded in the hedonic regressions.

Table 4 shows for which years and companies the data has been collected. The data cover motors from several companies. These companies are: ASEA, Luth \& Rosén,

Motorfabriken ECK, Svenska elektromekaniska AB, AEG and Siemens. ${ }^{25}$ The two latter companies were German, while the others were Swedish. Most of the data was collected from ASEA, which was a very large producer of standardized electric motors in 1900-35 (Glete 1983). The data of characteristics and prices for two consecutive years are not necessarily from the same company. It is thus assumed that companies had the same price strategies for the adjacent years that are investigated. Qualitative evidence indicates that there was strong competition among electric motor manufacturers until 1925 (see section 6.1). However, it is probable that there were price differences depending on for example

\footnotetext{
${ }^{24}$ It is probable that electric motors with more than 500 horsepower may have differed substantially in price, depending on the specifications by each user.

${ }^{25}$ ASEA is currently named Asea Brown Boveri (ABB) after a merger with the Swiss firm Brown Boveri in 1988. Motorfabriken ECK changed name to Elektriska AB Morén in 1925.
} 
reliability and brand name. These types of quality aspects are difficult to measure by hedonic and matched model price indexes. ${ }^{26}$

Table 4 also shows the number and the average horsepower of the electric motors for each year. The sample of electric motors and characteristics include 2121 observations. The minimum number of observations for one single year is 18 for the years 1901 and 1902. Moreover, the average horsepower differs between 7.8 and 37.5. The number of average horsepower is especially low for the years 1914 and 1933. This means that the samples for these years include many small motors compared to other years. However, even if electric motors with more than 20 horsepower are excluded in the regressions, the results remain robust for the adjacent years $1913-14,1914-15,1931-33$ and $1933-35{ }^{27}$

One problem with the collected data is that they are based on list prices. Calculations by Ljungberg (1990) of actual transaction prices of 30 electric motors purchased by the Swedish company Kockums 1914-20 indicate that list prices may differ from transaction prices. It is likely that the list prices differed from actual transaction prices, especially when large quantities of machines were bought. Nonetheless, it is probable that the change in list prices is a good proxy for the change in actual transaction prices.

One additional problem with constructing price indexes for electric motors is that it was not possible to find data on the number of electric motors sold. Therefore, it was not possible to construct weighted price indexes for electric motors. All the price indexes calculated are therefore unweighted price indexes, where all motors have equal weights. This might be a problem if motors that were not sold in large quantities differ substantially in price from motors that were sold in large quantities.

A producer price index (PPI) was used in order to convert current to constant prices. The PPI for Sweden 1900-35 is presented in figure $1 .^{28}$ The annual decrease in producer prices was estimated to be 0.6 percent 1900-1914. In 1914-20 producer prices increased by 21.6 percent per year. The annual decrease in producer prices was 16.2 percent in 1920-24, but only 2.4 percent in 1924-35. On average, producer prices increased by 0.3 percent per year 1900-35. Figure 1 shows that World War I had a very large effect on producer prices. The unstable prices during World War I makes it difficult to draw conclusions based on price estimates for this period.

\section{Results}

\subsection{The hedonic regression}

The results of the hedonic regressions are shown in table 5. Both current and PPI-deflated prices were used for each pair of adjacent years and a dummy variable has been included

\footnotetext{
${ }^{26}$ It is possible to use a dummy variable for different brand names. However, the data for electric motors for most years are based on only one company, which makes it difficult to use dummy variables for brand names in this paper.

${ }^{27}$ To make sure that there is no problem with heteroskedasticity, White heteroskedasticity-consistent standard errors and covariance have been used to estimate all regressions.

${ }^{28}$ The PPI is based on calculations by Ljungberg (1990).
} 
for the later of the years. According to the results the adjusted $R^{2}$ value varies between 0.90 and 0.99 depending on the period that is used for estimation. The $R^{2}$ values are very high compared to many other regressions. However, according to Triplett (2004) it is not unusual that the $R^{2}$ value exceeds 0.9 in hedonic regressions. Nonetheless, a high $R^{2}$ value alone does not mean that there are no omitted variables. Knowledge of the product is often much more important for determining whether some important variable have been omitted from the regressions.

Most of the estimated coefficients are significant at the $1 \%$ level, which indicates that the selected characteristics are important for prices. Both the power and the maximum voltage coefficients have a positive effect on the price. ${ }^{29}$ The coefficient of speed has a negative impact on the price. This implies that low speed motors were more expensive than motor with high speed. The estimated coefficients of the time dummy variable are significant for most years.

\subsection{The hedonic price index}

Table 6 presents the results of the hedonic price index as the rate of change for each of the adjacent years and as a price index. The main findings are that current and PPIdeflated prices decreased at an average rate of 2.2 and 2.6 percent per year 1900-35. However, the price decrease depends very much on which time periods that are analyzed. Figure 2 shows the hedonic price indexes for electric motors in current and PPI-deflated prices $(1900=100)$. Until 1913 prices and characteristics were only observed for a few years. ${ }^{30}$ Nonetheless, according to figure 2 the hedonic prices decreased substantially during the first years of the 1900s. The prices then increased in 1904 and then continued to decrease until 1914.

During World War I the prices increased substantially, especially in 1917 when the PPIdeflated prices for electric motors increased by 117 percent compared to 1916 . After 1917 the price trend was clearly decreasing. During the period of high productivity growth 1920-29 the current prices of electric motors decreased by approximately 13.2 percent per year. The corresponding figure in PPI-deflated prices was 4.8 percent per year in 1920-29. However, there were some years during the 1920s when prices for electric motors increased. For example, in 1925 and 1929 hedonic prices increased substantially. ${ }^{31}$

\subsection{The matched model price index}

Table 7 shows results of the matched model price index and the share of electric motors that were matched for each pair adjacent years. Current and PPI-deflated prices decreased by 1.3 and 1.6 percent per year in 1900-35. This indicates that prices for electric motors based on the matched model methodology decreased less rapidly than the prices based on

\footnotetext{
${ }^{29}$ For the period $1924-25$, maximum voltage is excluded from the regression. The reason is that all electric motors in the sample were produced for a maximum voltage of 500 volts.

${ }^{30}$ This means that for the period 1900-13 the estimated coefficients are kept constant for considerably longer time periods than in 1913-25.

${ }^{31}$ One possible explanation for the increase in hedonic prices in 1925 is discussed in section 6.
} 
the hedonic methodology 1900-35. ${ }^{32}$ The annual price decrease in current and PPIdeflated prices was 12.2 and 3.7 percent in 1920-29.

The share of electric motors that were matched varies between 9 and 100 percent depending on the period that is analyzed. The average matching ratio was 27.7 percent in 1900-35. For the years 1901-02, 100 percent of the electric motors were matched. The price decrease was 9 percent in current prices and 7 percent in PPI-deflated prices. Exactly the same results are obtained by the hedonic price indexes 1901-02 (see table 6). This confirms the well known fact that hedonic and matched model price indexes produce identical results when 100 percent of the observations are matched.

\section{Analyzing and comparing different price indexes}

In this section the three questions that were posed in the introduction are analyzed in detail by using the results presented in section 5 .

\subsection{Productivity in the electric motor producing industry}

Kendrick (1961) estimates that the US labor productivity growth 1919-29 for Electric machinery was only 4.1 percent per year. This was below the average annual labor productivity growth rate of 5.1 percent in US manufacturing. The results presented in this paper suggest that electric motor prices in Sweden decreased substantially in 1920-29. The results are similar either if hedonic or matched model price indexes are used. According to the hedonic price index the annual price decrease was 13.2 percent, while it was 12.2 percent according to the matched model price index. In PPI-deflated prices the annual price decrease was 4.8 and 3.7 percent, based on hedonic and matched model price indexes. This indicates that prices decreased considerably more for electric motors compared to total manufacturing.

No matter which type of index that is being used it is evident that prices for electric motors decreased substantially during the 1920s in Sweden. Rapidly decreasing prices is a good indication of productivity growth as long as competition is unchanged. It thereby becomes very important to try to analyze if the competition remained reasonably constant in the Swedish market for electric motors 1900-35. There is no data available to test the market structure of the electric motor industry. However, it is possible to use results from qualitative research about the electric motor industry.

Glete (1983) documents the history of ASEA 1883-1983. ASEA was one of the largest producers of electric motors in Sweden $1900-35 .{ }^{33}$ According to Glete there was very strong competition in the market for electric motors until 1925. Many new companies began to produce standardized electric motors in 1900-24 and competition was fierce. But in 1925 a cartel was formed between the major producers of electric motors. The companies participating in the cartel were: ASEA, Luth\&Rosén, Elektromekano, AEG and Siemens. However, the cartel was not very strong and only functioned upon mutual agreement among all the companies (Glete 1983). The cartel could be one of the reasons

${ }^{32}$ This is further analyzed in section 6.2 .

${ }^{33}$ Glete (1983) also includes an overview of the other companies included in this investigation. 
why prices of electric motors increased rapidly in 1924-25. This price increase is indicated in the hedonic price index where PPI-deflated prices increased by 16.2 percent, but less strongly in the matched model price index, where the increase was 6.7 percent.

Figure 2 shows that the cartel did not have a very strong effect over a longer time period since the trend in prices of electric motors continued to decrease after 1925. Results from qualitative sources thereby support the view that the rapidly decreasing prices reflect increases in productivity. Even though there might have been less competition among electric motor manufacturers after 1925, the prices continued to decrease which is a strong indication of productivity growth.

Table 8 presents figures of labor productivity growth in Swedish Electric machinery in 1913-35. Labor productivity has been defined as production value per person employed. ${ }^{34}$ The hedonic and matched model price indexes estimated in this paper have been used to calculate production value in constant prices. ${ }^{35}$ Table 8 shows that the annual labor productivity growth in Swedish Electric machinery 1920-29 was 12.1 percent with hedonic deflators and 10.8 percent with matched model deflators. Thereby, there is strong evidence that productivity growth in the electric motor producing industry was very high during the 1920s. However, it is still a puzzle why productivity did not increase more in US Electric machinery during the 1920s.

\subsection{Comparing hedonic and matched model price indexes}

Figure 2 compares the hedonic price index with the matched model price index for current and PPI-deflated prices, respectively. For the whole period 1900-35 the hedonic price index is lower than the matched model price index for current as well as PPIdeflated prices. For the period 1900-35 the PPI-deflated hedonic price index decreased by 2.6 percent per year while the corresponding figure was 1.6 percent for the matched model price index. The annual difference is thus approximately 1 percentage point between the two price indexes in 1900-35. In 1920-29 the PPI-deflated hedonic and matched model price indexes decreased by 4.8 and 3.7 percent per year respectively. Thus, the difference was 1.1 percentage points.

For some years the hedonic and matched model price indexes for electric motors produce very different results. However, on average the difference between the two indexes was not larger than 1 percentage point. One possible explanation why matched model and hedonic price indexes differ is that prices of non-identical products are matched. In this paper I have tried to use similar requirements for matched model and hedonic price indexes. Nevertheless, it was not possible to match electric motors without allowing some variation of characteristics. This might be one of the reasons why the hedonic and matched model price indexes differ. Another explanation is that the price changes of matched models are not representative of price changes of unmatched models. However, hedonic and matched model price indexes produce similar results for many years even

\footnotetext{
${ }^{34}$ Unfortunately it has not been possible to calculate labor productivity based on value added which implies that only single deflation is used to calculate productivity.

${ }^{35}$ It is only the price index for slip-ring electric motors with 1-100 horsepower that has been used to calculate production value in constant prices for Electric machinery. Thereby, it is assumed that other electric motors would have a similar price development.
} 
when the share of matched models is low. Thus, there is no clear evidence that the hedonic and matched model price indexes would differ more for years with low shares of matched models compared to years with high shares.

\subsection{Comparing the electric motor with the computer}

The last question to be addressed is whether the price decrease of electric motors estimated by hedonic and matched model price indexes can challenge the rapidly decreasing prices for ICT-products such as computers. Berndt \& Rappaport (2001) use hedonic regressions based on three continuous characteristics to measure the price change in desktop computers and mobile computers 1976-99. Their regression model was kept simple in order to facilitate comparability and feasibility over a quarter-century time frame in the dynamic PC market. The three continuous characteristics are hard-disk memory in MB, processor speed in $\mathrm{MHz}$ and the amount of RAM in MB. They also include indicator variables for whether the model included a CD-ROM, if it was an Apple brand, IBM-compatible computer or any other brand. Moreover, they allow parameters for characteristics to vary annually and thereby permit a relatively unrestrictive impact of changes in characteristics on prices. ${ }^{36}$

Table 9 presents Berndt \& Rappaport's results for the price change for desktop and mobile computers in the US in 1976-99. The results are presented both for the Laspeyres index formula and the Paasche index formula. If the Laspeyres formula is used the desktop prices decreased on average by 30.1 percent per year in 1976-99, while prices of mobile computers decreased by 26.0 percent per year in 1983-99. The results differ with less than 1 percentage point per year if the Paasche index formula is substituted for the Laspeyres index. It is also interesting to note that the price decrease accelerated in 199499.

If the price development of electric motors is compared to that of computers it is clear that over a 25 -years period the prices of electric motors decreased much more slowly than the prices of computers when the hedonic methodology is used. There are some years when the hedonic prices of electric motors decreased by more than 30 percent per year, but these years were followed by increases in electric motor prices. It also appears that the prices of the electric motor were much more volatile compared to that of the computer. It is possible that one of the reasons for the high volatility was the effects of World War I.

Table 10 presents the average price change for different ICT-products based on hedonic and matched model price indexes for different countries and time periods. According to table 10 prices decreased more for all ICT-products, except TVs in Japan, when the hedonic method was used instead of the matched model. The difference in percentage points between the matched model and hedonic estimates varies considerably. For computers in France the average difference was 28.4 percentage points, while it was only 2.4 for PCs in Japan.

\footnotetext{
${ }^{36}$ One limitation in the data set used by Berndt and Rappaport is that the 1982-88 data contain transactions prices, while the data for 1976-81 and 1989-99 incorporate list prices. Moreover, for 1976-81 and 199399 they do not have access to quantity sales data, which implies that all models are weighted equally in their price indexes.
} 
For electric motor prices, the difference between hedonic and matched model price indexes was 1 percentage point per year in 1900-35. One possible reason why the difference between the matched model and hedonic price indexes is larger for computers compared to electric motors is that there were considerably more new models of computers introduced. For example, the data set used by Berndt \& Rappaport (2001) consisted of 9 mobile models in 1983 and 1165 models in 1999. When new models are introduced they can often not be matched, but still affect the hedonic index. Hence, the price changes of matched models are not representative of price changes of unmatched models.

To sum up, during the 1920s the hedonic and the matched model price estimates decreased by 13.2 percent and 12.2 percent per year, for electric motors in Sweden. The labor productivity growth 1920-29 becomes 12.1 percent per year if hedonic price estimates are used to calculate production value in constant prices. This suggests that there was high productivity growth in the industry producing electric motors during the 1920s. For computers and ICT equipment, prices decreased by more than 30 percent per year 1976-99. The results presented in table 9 suggest that prices for computers decreased more than 3 times as rapidly 1994-99 compared to electric motors 1920-29. Thereby, it is evident that the price decrease of electric motors cannot challenge the price decrease of computers and other ICT-products even if the hedonic methodology is applied to historical price data. This supports the findings by Jovanovic \& Rousseau (2005) that ICT seems to be technologically more revolutionary compared to electricity.

\section{Conclusions}

Productivity is a crucial measure of the impact of major technological breakthroughs. In order to correctly estimate productivity over time, it is necessary to have accurate price indexes. One of the major problems with constructing price indexes is to adjust for quality change. During the 1990s many statistical agencies began to use hedonic price indexes to adjust for the rapid quality change in ICT-products (van Mulligen 2003). But since hedonic price indexes were not used before, it is very difficult to compare estimates of productivity growth at the industry level for the ICT-revolution and previous breakthroughs. In this study hedonic price indexes are used also for electric equipment during the electrification in order to assess how that would affect prices and productivity.

A major effort was made to collect data on prices and characteristics for electric motors in Sweden 1900-35. These prices and characteristics were used to construct hedonic and matched model price indexes for electric motors. The estimated hedonic price indexes indicate that electric motor prices decreased at an annual rate of 2.2 and 2.6 percent in current and PPI-deflated prices respectively, in 1900-35. The corresponding figures for the matched model price index were 1.3 and 1.6 percent per year. During the 1920 s the hedonic and the matched model price change estimates decreased by 13.2 percent and 12.2 percent per year. The annual PPI-deflated price decrease in 1920-29 was 4.8 and 3.7 percent for hedonic and matched model price indexes, respectively.

No matter which type of index that is being used it is evident that prices for electric motors decreased substantially during the 1920s in Sweden. This indicates a high 
productivity growth in the electric motor industry in 1920-29. In 1925 a cartel was formed by companies manufacturing standardized electric motors. However, the cartel only had a temporary impact on electric motor prices. After a one-off price increase in 1925 , the trend in prices continued to be downward.

Using hedonic price indexes to deflate production value for Swedish Electric machinery annual labor productivity growth $1920-29$ was estimated to be 12.1 percent. ${ }^{37}$ For the period 1919-29 annual labor productivity growth in US manufacturing was 5.1 percent, while labor productivity growth in Electric machinery was 4.1 percent per year. The analysis in this paper suggests that productivity growth in the US Electric machinery industry would increase if hedonic and matched model price indexes were used also to deflate prices in US Electric machinery. However, there are also other potential explanations. For example, the US productivity figures are based on value added while the Swedish ones are based on production value. Value added price deflators may differ considerably from production value price deflators (Edquist 2005). This is because value added price deflators also depend on the price changes of inputs and the relation between value added and production value. ${ }^{38}$

This paper has also investigated if price changes for electric motors differ substantially, whether hedonic or matched model price indexes are used. The results show that hedonic price indexes decreased by 1 percentage point more per year than the matched model price indexes for 1900-35. For the period 1920-29 the annual difference was also 1 percentage point. The results indicate that the differences between the hedonic and matched model price indexes are not very large over a considerable period of time. Nonetheless, on a year-to-year basis the differences between the two price indexes can be large.

The price changes for electric motors 1900-35 were also compared with those of ICTproducts 1976-99. The results clearly showed that, over a longer time period, hedonic prices decreased considerably more rapidly for computers compared to electric motors. According to Berndt \& Rappaport (2001) the hedonic price change for desktop computers decreased on average by 30.1 percent per year 1976-99. The annual price decrease for electric motors, estimated by hedonic price indexes, was 2.2 percent in 1900-35 and 13.2 percent in 1920-29. The conclusion is that over a longer period of time, electric motor prices did not decrease as much as computer prices even if hedonic price methods are used for electric motors.

The results also show that the hedonic and the matched model price indexes differ considerably more for ICT-products than for electric motors. One explanation to this could be that there were considerably more new models introduced for computers than for electric motors. When new models are introduced they can often not be matched, but affect the hedonic price index. Finally, the results show that the price decrease of electric motors cannot rival the price decrease of computers and other ICT-products even if the hedonic methodology is applied to historical price data.

\footnotetext{
${ }^{37}$ The corresponding figure for the matched model price index is 10.8 percent per year (see table 8).

${ }^{38}$ Another explanation to the different productivity results for US and Swedish Electric machinery could be that Swedish Electric machinery simply was more productive than the US. Moreover, it is also possible that the price decrease of other electric motor models decreased less rapidly than the electric motors used in this study.
} 


\section{References}

ASEA, (1900-35), Price Lists Collected at the ASEA archives, Västerås, Sweden.

Berndt, Ernst R. and Rappaport, Neal J. (2001), "Price and Quality Desktop and Mobile Personal Computers: A Quarter-Century Historical Overview," American Economic Review, Vol. 91, No. 2, pp. 268-273.

Berndt, Ernst R., Griliches, Zvi and Rappaport, Neal J. (1995), "Econometric estimates of price indexes for personal computers in the 1990's," Journal of Econometrics, Vol. 68, No. 1, pp. 243-268.

Bresnahan, Timothy F. and Trajtenberg, Manuel (1995), "General Purpose Technologies 'Engines of Growth'?," Journal of Econometrics, Vol. 65, No. 1, pp. 83-108.

Court, Andrew (1939), "Hedonic Price Indexes with Automotive Examples," In The Dynamics of Automobile Demand, New York, NY: General Motors Corporation, pp. 99-117.

Crafts, Nicholas (2002), "Productivity Growth in the Industrial Revolution: A New Growth Accounting Perspective," Working Paper, London School of Economics.

Crafts, Nicholas (2004), "Steam as a General Purpose Technology: A Growth Accounting Perspective," Economic Journal, Vol. 114, No. 495, pp. 338-351.

David, Paul A. (1990), "The Dynamo and the Computer: An Historical Perspective on the Modern Productivity Paradox,” American Economic Review, Vol. 80, No. 2, pp. 355-361.

David, Paul A. (1991), "Computer and Dynamo: The modern productivity paradox in a not-to-distant mirror," In Technology and Productivity: The Challenge for Economic Policy, OECD, Paris.

Devine, Warren (1983), "From Shaft to Wires: Historical Perspective on Electrification,” Journal of Economic History, Vol. 43, No. 2, pp. 347-372.

Edquist, Harald (2005), “The Swedish ICT - Miracle Myth or Reality?,” Information, Economics and Policy, forthcoming.

Edquist, Harald and Henrekson, Magnus (2004), “Technological Breakthroughs and Productivity Growth," Working paper 562, Stockholm School of Economics.

Freeman, Christopher and Soete, Luc (eds) (1987), Technical Change and Full Employment, Basil Blackwell, New York.

Glete, Jan (1983), Asea under hundra år 1883-1983: En studie i ett storföretags organisatoriska, tekniska och ekonomiska utveckling, Stenströms Bokförlag, Stockholm.

Gordon, Robert J. (1990), The Measurement of Durable Goods Prices, The University of Chicago Press, Chicago.

Gordon, Robert J. (2000), "Does the 'New Economy' Measure up to the Great Inventions of the Past?," Journal of Economic Perspectives, Vol. 14, No. 4, pp. 49-74.

Griliches, Zvi (1961), "Hedonic Price Indexes for Automobiles: An Economic Analysis of Quality Change”. In The Price Statistics of the Federal Government: Review, Appraisal, and Recommendations, General Series No. 73. New York, NY: National Bureau of Economic Research, pp. 173-96.

ILO (2004), Consumer price index manual: Theory and practice, ILO Publications, Geneva. 
Jovanovic, Boyan and Rousseau, Peter L. (2005), "General Purpose Technologies," NBER Working Paper No. 11093, Cambridge, MA.

Kendrick, John W. (1961), Productivity Trends in the United States, Princeton University Press, Princeton.

Kommerskollegium (1900-35), Industri, Stockholm.

Lipsey, Richard G., Bekar, Cliff and Carlaw, Ken (1998), “The Consequences of Changes in GPTs,” In Helpman, Elhanan (ed.), General Purpose Technologies and Economic Growth, MIT Press, Cambridge.

Litan, Robert E. and Rivlin, Alice M. (2001), Beyond the dot.coms, Brookings Institution Press, Washington DC.

Ljungberg, Jonas (1990), Priser och marknadskrafter i Sverige 1885-1969: En prishistorisk studie, Studentlitteratur, Lund.

Ljungberg, Jonas (1996), 'Prices and Growth Accounting,” In Buyst, Erik., Dejongh, Guy., van Ark, Bart and van Zanden, Jan Luiten (eds) (1996), Historical Benchmark Comparisons of Output and Productivity, 1750-1990, Research paper 96.03, Leuven.

OECD (2002), Measuring the information Economy, OECD Working Paper, Paris.

Pindyck, Robert S. and Rubinfeld, Daniel L. (1998), Econometric Models and Economic Forecasts, Irwin McGraw-Hill, Boston.

Raff, Daniel M. G. and Trajtenberg, Manuel (1997), "Quality-Adjusted Prices for the American Automobile Industry: 1996-1940," In Bresnahan, Timothy and Gordon, Robert J. (1997), The Economics of New Goods, University of Chicago Press, Chicago.

Rosen, Sherwin (1974), "Hedonic Prices and Implicit Markets: Product Differentiation in Pure Competition,” Journal of Political Economy, Vol. 82, No. 1, pp. 34-55.

Scarpetta, Stefano, Bassanini, Andrea, Pilat, Dirk and Schreyer, Paul (2000), "Economic Growth in the OECD Area: Recent Trends at the Aggregate and Sectoral Level," Economics Department, Working Paper No. 248, OECD, Paris.

Schön, Lennart (1988), Historiska nationalräkenskaper för Sverige: Industri och hantverk 1800-1980, Ekonomisk-Historiska Föreningen, Lund.

Schön, Lennart (2000), "Electricity, Technological Change and Productivity in Swedish Industry, 18901990,” European Review of Economic History, Vol. 4, No. 2, pp. 175-194.

Statistics Sweden (1960), Historical Statistics of Sweden, Stockholm.

Swedish Royal Library (1900-35), Price Lists Collected at the Swedish Royal Library Archives, Stockholm, Sweden.

Triplett, Jack E. (2004), Handbook on Hedonic Indexes and Quality Adjustment in Price Indexes, Directorate for Science, Technology and Industry. OECD, Paris.

van Ark, Bart, Inklaar, Robert and McGuckin, Robert H. (2002), "Changing Gear: Productivity, ICT and Service Industries: Europe and the United States," Research Memorandum GD-60, Groningen Growth and Development Centre, Groningen.

Van Mulligen, Peter Hein (2003), Quality Aspects in Price Indices and International Comparisons: Applications of the Hedonic Method, Voorburg, Statistics Netherlands.

Waugh, Frederick V. (1928), "Quality Factors Influencing Vegetable Prices," Journal of Farm Economics, Vol. 10, No. 2, pp. 185-196. 


\section{Appendix}

\section{Appendix A: Hedonic price indexes}

Suppose that $\hat{B}^{1}$ is the estimated coefficient of the $D^{1}$ time dummy variable in equation (1). The coefficient $\hat{B}^{1}$ in equation (1) is an estimate of the price index between period $t$ and $t+1$. For a hedonic function with a logarithmic dependent variable the formula for the dummy variable index is:

index $\{(t+1) / t\}=\exp \left(\hat{B}^{1}\right)=\left[\frac{\prod_{i=1}^{I}\left(p_{i, t+1}\right)^{1 / n}}{\prod_{i=1}^{I}\left(p_{i, t}\right)^{1 / m}}\right] \div[H Q A]$

The dummy variable index equals the ratio of an unweighted geometric mean of prices in periods $t$ and $t+1$ divided by a hedonic quality adjustment (HQA). In the usual case, hedonic regressions are run on unbalanced samples, so the number of observations may differ in the two periods as indicated by the subscripts $m$ and $n$.

The hedonic quality adjustment depends on the form of the hedonic function. For the double-log hedonic function, the hedonic quality adjustment is given by:

$H Q A=\exp \left[\sum_{k=1}^{K} \hat{a}_{k}\left(\left(\sum_{k=1}^{K} z_{i k}^{t+1} / n\right)-\left(\sum_{k=1}^{K} z_{i k}^{t} / m\right)\right)\right]$

Equation (5) is a quantity index that measures the change in characteristics of electric motors sold in periods $t$ and $t+1$. The terms in square brackets are the mean change in characteristics between periods $t$ and $t+1$. The changes in characteristics are valued by their implicit prices, which are the $\hat{a}_{k}$ coefficients from the hedonic function (see equation (1)). 


\section{Tables and figures}

Table 1 Average annual labor- and total factor productivity growth in US manufacturing 1899-1937 (percent)

\begin{tabular}{|c|c|c|c|c|c|c|c|c|}
\hline \multirow[t]{2}{*}{ Industry } & \multicolumn{2}{|c|}{ 1899-1909 } & \multicolumn{2}{|c|}{ 1909-1919 } & \multicolumn{2}{|c|}{$1919-1929$} & \multicolumn{2}{|c|}{ 1929-1937 } \\
\hline & LP & TFP & LP & TFP & LP & TFP & LP & TFP \\
\hline Food & 0.2 & 0.3 & -1.0 & -0.4 & 4.9 & 5.3 & -0.5 & 1.5 \\
\hline Beverages & 0.1 & 0.9 & -6.9 & -5.6 & 0.3 & -0.2 & 13.2 & 15.2 \\
\hline Tobacco & 1.4 & 1.2 & 5.6 & 4.9 & 6.8 & 4.4 & 5.4 & 6.3 \\
\hline Textiles & 1.1 & 1.1 & -0.1 & 0.9 & 3.0 & 2.9 & 0.9 & 4.6 \\
\hline Apparel & 0.3 & 0.7 & 1.5 & 2.7 & 4.0 & 4.0 & -0.6 & 2.5 \\
\hline Lumber products & -0.5 & -0.4 & -1.5 & -1.2 & 1.9 & 2.5 & -0.8 & 0.4 \\
\hline Furniture & -1.0 & -0.8 & -0.9 & -0.5 & 3.9 & 4.2 & -1.5 & 0.5 \\
\hline Paper & 2.4 & 2.4 & -0.4 & 0.3 & 5.3 & 4.6 & 1.6 & 4.3 \\
\hline Printing, publishing & 3.3 & 3.9 & 2.7 & 3.0 & 3.9 & 3.7 & 0.3 & 2.6 \\
\hline Chemicals & 1.1 & 0.7 & -1.2 & -0.7 & 7.5 & 7.4 & 1.6 & 3.0 \\
\hline Petroleum, coal products & 2.2 & 0.7 & 0.7 & -1.0 & 8.6 & 8.6 & 1.2 & 2.7 \\
\hline Rubber products & 2.4 & 2.3 & 6.6 & 7.4 & 8.3 & 7.7 & 0.5 & 4.0 \\
\hline Leather products & 0.2 & 0.1 & -0.6 & 0.5 & 2.2 & 2.9 & 0.8 & 3.6 \\
\hline Stone, clay, glass & 2.5 & 2.2 & 0.5 & 0.7 & 5.2 & 5.7 & 0.9 & 2.3 \\
\hline Primary metals & 3.9 & 2.7 & -1.2 & -0.5 & 4.8 & 5.5 & -2.9 & -1.3 \\
\hline Fabricated metals & 2.3 & 2.3 & 1.2 & 1.8 & 4.6 & 4.6 & -0.8 & 1.0 \\
\hline Machinery, nonelectric & 1.3 & 1.0 & 0 & 0.7 & 3.5 & 2.9 & -0.3 & 2.3 \\
\hline Electric machinery & 0.5 & 0.6 & -0.9 & 0.3 & 4.1 & 3.5 & 0.5 & 3.2 \\
\hline Transportation equipment & 1.0 & 1.1 & 5.7 & 7.0 & 9.1 & 8.4 & -2.2 & -0.4 \\
\hline Miscellaneous & 0.8 & 0.8 & -1.5 & -0.6 & 4.9 & 4.6 & 1.4 & 2.9 \\
\hline Total Manufacturing & 1.0 & 0.7 & 0.2 & 0.3 & 5.1 & 5.3 & 0.3 & 1.9 \\
\hline
\end{tabular}

Note: Labor productivity is defined as output per person employed. LP=labor productivity; TFP=total factor productivity.

Source: Kendrick (1961).

Table 2 Average annual labor productivity growth for different Swedish industries, 1913-46 (percent)

\begin{tabular}{l|cccc}
\hline Industry & $\mathbf{1 9 1 3 - 1 9 1 9}$ & $\mathbf{1 9 1 9 - 1 9 2 9}$ & $\mathbf{1 9 2 9 - 1 9 3 9}$ & $\mathbf{1 9 3 9 - 1 9 4 6}$ \\
\hline Ore-mining and metal industries & -2.2 & 4.3 & 2.8 & -2.3 \\
Non-metallic mining and quarrying & -3.6 & 4.7 & 4.9 & 0.2 \\
Wood and cork & 0.0 & 0.3 & 1.1 & 3.4 \\
Paper and paper products, printing & -2.1 & 4.5 & 3.0 & 2.1 \\
and allied industries & & & & \\
Food manufacturing industries & 0.0 & 2.8 & 2.1 & -0.4 \\
Textiles, wearing apparel and & -0.6 & 1.6 & 1.0 & -0.5 \\
made-up textile goods & & & & \\
Leather, furs and rubber products & -2.5 & 0.1 & 1.0 & 2.8 \\
Chemicals and chemical products & -5.7 & 11.5 & 4.6 & 0.7 \\
Power, lighting and waterworks & -0.1 & 7.9 & 5.3 & 4.6 \\
Total & $\mathbf{- 1 . 3}$ & $\mathbf{3 . 8}$ & $\mathbf{2 . 7}$ & $\mathbf{0 . 2}$ \\
\hline
\end{tabular}

Note: Labor productivity is defined as value added per person employed. 
Sources: Schön (1988), Statistics Sweden (1960) and own calculations.

Table 3 Annual labor productivity growth of ICT-producing, ICT-using and non-ICT industries in the EU and the US, 1990-95 vs. 1995-2000 (percent)

\begin{tabular}{l|cccc}
\hline & \multicolumn{3}{|c}{ United States } & \multicolumn{3}{c}{$\boldsymbol{E U}$} \\
\hline & $1990-1995$ & $1995-2000$ & $1990-1995$ & $1995-2000$ \\
Total Economy & 1.1 & 2.5 & 1.9 & 1.4 \\
ICT-producing industries & 8.1 & 10.1 & 6.7 & 8.7 \\
...ICT-producing Manufacturing & 15.1 & 23.7 & 11.1 & 13.8 \\
...ICT-producing Services & 3.1 & 1.8 & 4.4 & 6.5 \\
ICT-using Industries $\dagger$ & 1.5 & 4.7 & 1.7 & 1.6 \\
...ICT-using Manufacturing & -0.3 & 1.2 & 3.1 & 2.1 \\
...ICT-using Services & 1.9 & 5.4 & 1.1 & 1.4 \\
Non-ICT Industries & 0.2 & 0.5 & 1.6 & 0.7 \\
...Non-ICT Manufacturing & 3.0 & 1.4 & 3.8 & 1.5 \\
...Non-ICT Services & -0.4 & 0.4 & 0.6 & 0.2 \\
...Non-ICT Other & 0.7 & 0.6 & 2.7 & 1.9 \\
\hline
\end{tabular}

Note: Labor productivity is defined as value added per person employed. †Excluding ICT-producing industries. EU includes Austria, Denmark, Finland, France, Germany, Ireland, Italy, Netherlands, Spain, Sweden and the United Kingdom, which represents over 90 percent of the EU GDP.

Source: van Ark et al. (2002). 
Table 4 Companies, number of motors and average horsepower for the collected data of electric motors

\begin{tabular}{l|lcc}
\hline Year & Company & $\begin{array}{c}\text { Number of } \\
\text { motors }\end{array}$ & $\begin{array}{c}\text { Average } \\
\text { horsepower }\end{array}$ \\
\hline 1900 & ASEA, AEG & 60 & 20,3 \\
1901 & ASEA & 18 & 24,6 \\
1902 & ASEA & 18 & 24,6 \\
1903 & ASEA & 21 & 26,6 \\
1904 & ASEA; Luth \& Rosén & 125 & 28,8 \\
1908 & ASEA & 56 & 30,5 \\
1913 & ASEA; Motorfabriken ECK & 109 & 29,2 \\
1914 & ASEA & 32 & 7,8 \\
1915 & Motorfabriken ECK & 39 & 22,8 \\
1916 & ASEA & 253 & 35,9 \\
1917 & Motorfabriken ECK & 47 & 37,5 \\
1918 & Luth \& Rosén & 28 & 14,7 \\
1919 & Elektromekano & 33 & 14,5 \\
1920 & Motorfabriken ECK; Luth \& Rosén & 120 & 28,1 \\
1921 & Luth \& Rosén & 82 & 35,9 \\
1924 & Elektromekano & 22 & 17,7 \\
1925 & Luth \& Rosén & 78 & 36,8 \\
1926 & ASEA; Elektromekano & 266 & 31,7 \\
1928 & ASEA; Luth \& Rosén; AEG & 151 & 20,2 \\
1929 & ASEA & 128 & 15,8 \\
1930 & Luth \& Rosén & 55 & 19,2 \\
1931 & ASEA; AEG & 240 & 23,8 \\
1933 & Siemens & 66 & 8,2 \\
1935 & Elektriska AB Morén & 74 & 17,0 \\
\hline
\end{tabular}

Sources: ASEA (1900-35) and the Swedish Royal Library (1900-35). 
Table 5 Hedonic price regressions for alternating current slip-ring electric motors in Sweden 1900-35, adjacent years

\begin{tabular}{|c|c|c|c|c|c|c|c|}
\hline Period & Constant & Horsepower & $\begin{array}{l}\text { Rate per } \\
\text { minute }\end{array}$ & $\begin{array}{c}\text { Max } \\
\text { voltage }\end{array}$ & $\begin{array}{c}\text { Time- } \\
\text { dummy }\end{array}$ & $\overline{A d j} R^{2}$ & $N$ \\
\hline 1900-1901 & & & & & & & \\
\hline Current prices & $7.59 * * *$ & $0.55^{* * *}$ & -0.20 & -0.03 & $-0.39 * * *$ & 0.93 & 78 \\
\hline $\begin{array}{l}\text { Constant prices } \\
\text { 1901-1902 }\end{array}$ & $7.59 * * *$ & $0.55 * * *$ & -0.20 & -0.03 & $-0.32 * * *$ & 0.92 & 78 \\
\hline Current prices & $5.04 * * *$ & $0.53 * * *$ & -0.08 & $0.17 * * *$ & $-0.07 * *$ & 0.99 & 36 \\
\hline $\begin{array}{l}\text { Constant prices } \\
\text { 1902-1903 }\end{array}$ & $5.04 * * *$ & $0.53 * * *$ & -0.08 & $0.17 * * *$ & $-0.10 * * *$ & 0.99 & 36 \\
\hline Current prices & $6.31 * * *$ & $0.46 * * *$ & $-0.27 * *$ & $0.19 * * *$ & $-0.09 * *$ & 0.98 & 39 \\
\hline $\begin{array}{l}\text { Constant prices } \\
\text { 1903-1904 }\end{array}$ & $6.32 * * *$ & $0.46^{* * *}$ & $-0.27 * *$ & $0.19^{* * *}$ & $-0.07 * *$ & 0.98 & 39 \\
\hline Current prices & $8.61 * * *$ & $0.49 * * *$ & $-049 * * *$ & $0.05 * *$ & $0.20 * * *$ & 0.94 & 146 \\
\hline $\begin{array}{l}\text { Constant prices } \\
\mathbf{1 9 0 4 - 1 9 0 8}\end{array}$ & $8.61^{* * *}$ & $0.49 * * *$ & $-0.49 * * *$ & $0.05 * *$ & $0.21^{* * *}$ & 0.94 & 146 \\
\hline Current prices & $8.75^{* * *}$ & $0.48 * * *$ & $-0.49 * * *$ & $0.06^{* * *}$ & 0.008 & 0.93 & 181 \\
\hline $\begin{array}{l}\text { Constant prices } \\
\mathbf{1 9 0 8 - 1 9 1 3}\end{array}$ & $8.75 * * *$ & $0.48 * * *$ & $-0.49 * * *$ & $0.06^{* * *}$ & -0.03 & 0.93 & 181 \\
\hline Current prices & $7.71 * * *$ & $0.48 * * *$ & $-0.46 * * *$ & $0.18^{* * *}$ & $-0.31 * * *$ & 0.96 & 165 \\
\hline $\begin{array}{l}\text { Constant prices } \\
\text { 1913-1914 }\end{array}$ & $7.71 * * *$ & $0.48 * * *$ & $-0.46 * * *$ & $0.18^{* * *}$ & $-0.28 * * *$ & 0.96 & 165 \\
\hline Current prices & $6.99 * * *$ & $0.49 * * *$ & $-0.50 * * *$ & $0.28 * * *$ & $-0.36 * * *$ & 0.98 & 141 \\
\hline $\begin{array}{l}\text { Constant prices } \\
\text { 1914-1915 }\end{array}$ & $6.99 * * *$ & $0.49 * * *$ & $-0.50 * * *$ & $0.27 * * *$ & $-0.37 * * *$ & 0.98 & 141 \\
\hline Current prices & $8.53 * * *$ & $0.50 * * *$ & $-0.50 * * *$ & -0.03 & $0.34 * * *$ & 0.99 & 71 \\
\hline $\begin{array}{l}\text { Constant prices } \\
\text { 1915-1916 }\end{array}$ & $8.53 * * *$ & $0.50 * * *$ & $-0.50 * * *$ & -0.03 & $0.20 * * *$ & 0.99 & 71 \\
\hline Current prices & $5.75^{* * *}$ & $0.49 * * *$ & $-0.27 * * *$ & $0.20 * * *$ & $0.36^{* * *}$ & 0.98 & 292 \\
\hline $\begin{array}{l}\text { Constant prices } \\
\text { 1916-1917 }\end{array}$ & $5.75 * * *$ & $0.49 * * *$ & $-0.27 * * *$ & $0.20 * * *$ & $0.12 * * *$ & 0.98 & 292 \\
\hline Current prices & $6.34 * * *$ & $0.50 * * *$ & $-0.30 * * *$ & $0.19 * * *$ & $1.10 * * *$ & 0.98 & 300 \\
\hline $\begin{array}{l}\text { Constant prices } \\
1917-1918\end{array}$ & $6.34 * * *$ & $0.50 * * *$ & $-0.30 * * *$ & $0.19 * * *$ & $0.78 * * *$ & 0.97 & 300 \\
\hline Current prices & $10.15^{* * * *}$ & $0.52 * * *$ & $-0.63 * * *$ & $0.11 * * *$ & -0.03 & 0.97 & 75 \\
\hline $\begin{array}{l}\text { Constant prices } \\
\text { 1918-1919 }\end{array}$ & $10.15^{* * *}$ & $0.52 * * *$ & $-0.63 * * *$ & $0.11 * * *$ & $-0.28 * * *$ & 0.98 & 75 \\
\hline Current prices & $9.10 * * *$ & $0.50 * * *$ & $-0.51 * * *$ & $0.15 * * *$ & -0.03 & 0.98 & 61 \\
\hline $\begin{array}{l}\text { Constant prices } \\
\text { 1919-1920 }\end{array}$ & $9.10 * * *$ & $0.50 * * *$ & $-0.51 * * *$ & $0.15^{* * *}$ & $-0.09 * * *$ & 0.98 & 61 \\
\hline Current prices & $8.48 * * *$ & $0.47 * * *$ & $-0.54 * * *$ & $0.29 * * *$ & $0.12 * * *$ & 0.94 & 153 \\
\hline $\begin{array}{l}\text { Constant prices } \\
\text { 1920-1921 }\end{array}$ & $8.48 * * *$ & $0.47 * * *$ & $-0.54 * * *$ & $0.29 * * *$ & -0.05 & 0.93 & 153 \\
\hline Current prices & $8.62 * * *$ & $0.51 * * *$ & $-0.46 * * *$ & $0.18 * * *$ & $-0.55 * * *$ & 0.94 & 202 \\
\hline $\begin{array}{l}\text { Constant prices } \\
\text { 1921-24 }\end{array}$ & $8.62 * * *$ & $0.51 * * *$ & $-0.46^{* * *}$ & $0.18 * * *$ & $-0.23 * * *$ & 0.93 & 202 \\
\hline Current prices & $8.98 * * *$ & $0.55^{* * *}$ & $-0.46 * * *$ & 0.03 & $-0.77 * * *$ & 0.98 & 104 \\
\hline Constant prices & $8.98 * * *$ & $0.55^{* * * *}$ & $-0.46^{* * *} *$ & 0.04 & $-0.38 * * *$ & 0.98 & 104 \\
\hline
\end{tabular}

Sources: ASEA (1900-1935), the Swedish Royal Library (1900-1935) and own calculations. 
(continued)

\begin{tabular}{|c|c|c|c|c|c|c|c|}
\hline & Constant & Horsepower & $\begin{array}{l}\text { Rate per } \\
\text { minute }\end{array}$ & $\begin{array}{c}\text { Max } \\
\text { voltage }\end{array}$ & $\begin{array}{c}\text { Time- } \\
\text { dummy }\end{array}$ & $\operatorname{Adj} R^{2}$ & $N$ \\
\hline 1924-25 & & & & & & & \\
\hline Current prices & $8.78 * * *$ & $0.58 * * *$ & $-0.52 * * *$ & - & $0.15 * * *$ & 0.97 & 100 \\
\hline $\begin{array}{l}\text { Constant prices } \\
\text { 1925-26 }\end{array}$ & $8.78 * * *$ & $0.58 * * *$ & $-0.52 * * *$ & - & $0.15 * * *$ & 0.97 & 100 \\
\hline Current prices & $8.02 * * *$ & $0.53 * * *$ & $-0.55 * * *$ & $0.21 * * *$ & $-0.12 * * *$ & 0.96 & 344 \\
\hline $\begin{array}{l}\text { Constant prices } \\
\mathbf{1 9 2 6 - 2 8}\end{array}$ & $8.02 * * *$ & $0.53 * * *$ & $-0.55 * * *$ & $0.21 * * *$ & $-0.08 * * *$ & 0.96 & 344 \\
\hline Current prices & $7.93 * * *$ & $0.54 * * *$ & $-0.55 * * *$ & $0.19 * * *$ & $-0.17 * * *$ & 0.94 & 417 \\
\hline $\begin{array}{l}\text { Constant prices } \\
\text { 1928-29 }\end{array}$ & $7.93 * * *$ & $0.54 * * *$ & $-0.55 * * *$ & $0.19 * * *$ & $-0.12 * * *$ & 0.94 & 417 \\
\hline Current prices & $8.82 * * *$ & $0.56 * * *$ & $-0.53 * * *$ & -0.0009 & $0.19 * * *$ & 0.90 & 279 \\
\hline $\begin{array}{l}\text { Constant prices } \\
\text { 1929-30 }\end{array}$ & $8.82 * * *$ & $0.56 * * *$ & $-0.53 * * *$ & -0.001 & $0.22 * * *$ & 0.90 & 279 \\
\hline Current prices & $8.42 * * *$ & $0.52 * * *$ & $-0.53 * * *$ & 0.10 & $-0.33 * * *$ & 0.93 & 183 \\
\hline $\begin{array}{l}\text { Constant prices } \\
\text { 1930-31 }\end{array}$ & $8.42 * * *$ & $0.52 * * *$ & $-0.53 * * *$ & 0.10 & $-0.28 * * *$ & 0.93 & 183 \\
\hline Current prices & $6.66 * * *$ & $0.55 * * *$ & $-0.47 * * *$ & $0.25 * * *$ & $0.05 * *$ & 0.95 & 295 \\
\hline $\begin{array}{l}\text { Constant prices } \\
\text { 1931-33 }\end{array}$ & $6.66 * * *$ & $0.55 * * *$ & $-0.47 * * *$ & $0.25 * * *$ & $0.12 * * *$ & 0.95 & 295 \\
\hline Current prices & $6.43 * * *$ & $0.54 * * *$ & $-0.43 * * *$ & $0.26 * * *$ & $0.18 * * *$ & 0.94 & 306 \\
\hline $\begin{array}{l}\text { Constant prices } \\
\text { 1933-35 }\end{array}$ & $6.43 * * *$ & $0.54 * * *$ & $-0.43 * * *$ & $0.26 * * *$ & $0.24 * * *$ & 0.94 & 306 \\
\hline Current prices & $5.10 * * *$ & $0.52 * * *$ & $-0.36 * * *$ & $0.42 * * *$ & $-0.24 * * *$ & 0.92 & 140 \\
\hline Constant prices & $5.10 * * *$ & $0.52 * * *$ & $-0.36 * * *$ & $0.42 * * *$ & $-0.28 * * *$ & 0.92 & 140 \\
\hline
\end{tabular}

Note: Significant at $1 \%=* * *, 5 \%=* *$ and $10 \%=*$. White heteroskedasticity-Consistent Standard Errors and Covariance.

Sources: ASEA (1900-1935), the Swedish Royal Library (1900-1935) and own calculations. 
Table 6 Hedonic price indexes for alternating current slip-ring electric motors in current and PPI-deflated prices in Sweden 1900-35

\begin{tabular}{|c|c|c|c|c|}
\hline \multirow[t]{2}{*}{ Year } & \multicolumn{2}{|c|}{ Rate of change using } & \multicolumn{2}{|c|}{ Index using } \\
\hline & Current prices & Constant prices & Current prices & Constant prices \\
\hline 1900 & - & - & 100 & 100 \\
\hline 1901 & -0.33 & -0.28 & 67.4 & 72.3 \\
\hline 1902 & -0.09 & -0.07 & 61.2 & 67.1 \\
\hline 1903 & -0.08 & -0.07 & 56.2 & 62.2 \\
\hline 1904 & 0.22 & 0.23 & 68.8 & 76.8 \\
\hline 1905-07 & - & - & - & - \\
\hline 1908 & 0.01 & -0.03 & 69.3 & 74.5 \\
\hline 1909-12 & - & - & - & - \\
\hline 1913 & -0.26 & -0.25 & 51.1 & 56.1 \\
\hline 1914 & -0.30 & -0.31 & 35.6 & 38.6 \\
\hline 1915 & 0.41 & 0.22 & 50.1 & 47.2 \\
\hline 1916 & 0.43 & 0.13 & 71.4 & 53.5 \\
\hline 1917 & 2.01 & 1.17 & 214.9 & 116.1 \\
\hline 1918 & -0.03 & -0.25 & 207.9 & 87.3 \\
\hline 1919 & -0.03 & -0.09 & 201.5 & 79.8 \\
\hline 1920 & 0.13 & -0.04 & 227.3 & 76.3 \\
\hline 1921 & -0.42 & -0.21 & 130.9 & 60.6 \\
\hline 1922-23 & - & - & - & - \\
\hline 1924 & -0.54 & -0.32 & 60.5 & 41.3 \\
\hline 1925 & 0.16 & 0.16 & 70.0 & 48.0 \\
\hline 1926 & -0.11 & -0.08 & 62.0 & 44.1 \\
\hline 1927 & - & - & - & - \\
\hline 1928 & -0.16 & -0.11 & 52.3 & 39.2 \\
\hline 1929 & 0.21 & 0.25 & 63.5 & 48.9 \\
\hline 1930 & -0.28 & -0.24 & 45.9 & 37.1 \\
\hline 1931 & 0.05 & 0.13 & 48.0 & 42.0 \\
\hline 1932 & - & - & - & - \\
\hline 1933 & 0.19 & 0.27 & 57.4 & 53.1 \\
\hline 1934 & - & - & - & - \\
\hline 1935 & -0.21 & -0.24 & 45.2 & 40.3 \\
\hline
\end{tabular}

Sources: ASEA (1900-1935), the Swedish Royal Library (1900-1935) and own calculations. 
Table 7 Matched model price indexes for alternating current slip-ring electric motors in current and PPI-deflated prices in Sweden 1900-35

\begin{tabular}{|c|c|c|c|c|c|}
\hline Year & \multicolumn{2}{|c|}{ Rate of change using } & \multicolumn{2}{|c|}{ Index using } & \multirow[t]{2}{*}{ Percentage matched } \\
\hline & $\begin{array}{l}\text { Current } \\
\text { prices }\end{array}$ & $\begin{array}{l}\text { Constant } \\
\text { prices }\end{array}$ & $\begin{array}{l}\text { Current } \\
\text { prices }\end{array}$ & $\begin{array}{l}\text { Constant } \\
\text { prices }\end{array}$ & \\
\hline 1900 & - & - & 100 & 100 & - \\
\hline 1901 & -0.23 & -0.17 & 77.2 & 82.8 & 13 \\
\hline 1902 & -0.09 & -0.07 & 70.1 & 76.9 & 100 \\
\hline 1903 & 0.002 & 0.01 & 70.2 & 77.7 & 26 \\
\hline 1904 & 0.20 & 0.20 & 84.0 & 93.7 & 11 \\
\hline $1905-07$ & - & - & - & - & - \\
\hline 1908 & 0.20 & 0.15 & 100.4 & 107.9 & 22 \\
\hline 1909-12 & - & - & - & - & - \\
\hline 1913 & -0.14 & -0.12 & 86.3 & 94.7 & 23 \\
\hline 1914 & -0.32 & -0.33 & 58.8 & 63.8 & 30 \\
\hline 1915 & 0.39 & 0.21 & 81.7 & 77.1 & 34 \\
\hline 1916 & 0.42 & 0.13 & 116.1 & 87.1 & 11 \\
\hline 1917 & 1.86 & 1.07 & 332.4 & 180.0 & 9 \\
\hline 1918 & -0.09 & -0.29 & 301.6 & 126.9 & 21 \\
\hline 1919 & -0.06 & -0.12 & 282.5 & 112.1 & 59 \\
\hline 1920 & -0.005 & -0.16 & 281.1 & 94.5 & 33 \\
\hline 1921 & -0.35 & -0.10 & 182.8 & 84.8 & 38 \\
\hline 1922-23 & - & - & - & - & - \\
\hline 1924 & -0.50 & -0.27 & 91.2 & 62.3 & 19 \\
\hline 1925 & 0.06 & 0.07 & 96.8 & 66.5 & 26 \\
\hline 1926 & -0.07 & -0.04 & 89.6 & 63.9 & 29 \\
\hline 1927 & - & - & - & - & - \\
\hline 1928 & -0.12 & -0.07 & 78.7 & 59.1 & 35 \\
\hline 1929 & 0.11 & 0.14 & 87.1 & 67.2 & 27 \\
\hline 1930 & -0.24 & -0.20 & 66.6 & 53.9 & 22 \\
\hline 1931 & 0.03 & 0.12 & 68.9 & 60.3 & 27 \\
\hline 1932 & - & - & - & - & - \\
\hline 1933 & 0.21 & 0.28 & 83.4 & 77.3 & 16 \\
\hline 1934 & - & - & - & - & - \\
\hline 1935 & -0.23 & -0.26 & 64.0 & 57.2 & 9 \\
\hline
\end{tabular}

Sources: ASEA (1900-1935), the Swedish Royal Library (1900-1935) and own calculations.

Table 8 Labor productivity growth in Electric machinery in Sweden 1913-35 (percent)

\begin{tabular}{l|cc}
\hline Year & \multicolumn{2}{|c}{ Growth rate } \\
\hline & Hedonic deflation & Matched model deflation \\
$1913-1919$ & -7.2 & -4.2 \\
$1920-1929$ & 12.1 & 10.8 \\
$1930-1935$ & -2.5 & -2.0 \\
$1913-1935$ & 3.0 & 3.8 \\
\hline \multicolumn{2}{l}{ Note: Labor productivity is defined as production value per person employed. }
\end{tabular}

Source: Kommerskollegium (1900-35) and own calcultions 
Table 9 Average annual price change for desktop and mobile computers in the US 1976-1999 based on hedonic price indexes

\begin{tabular}{l|cccc}
\hline Year & \multicolumn{3}{|c}{ Laspeyres } & \multicolumn{2}{c}{ Paasche } \\
\hline & Desktop & Mobile & Desktop & Mobile \\
$1976-83$ & -23.2 & n.a. & -21.8 & n.a. \\
$1983-89$ & -24.8 & -15.8 & -24.6 & -15.8 \\
$1989-94$ & -34.5 & -19.4 & -30.2 & -18.0 \\
$1994-99$ & -40.0 & -41.8 & -42.2 & -41.2 \\
& & & & \\
$1976-99$ & -30.1 & n.a. & -29.2 & n.a. \\
$1983-99$ & -32.9 & -26.0 & -32.2 & -25.3 \\
\hline
\end{tabular}

Note: $\mathrm{n} . \mathrm{a}$ indicates not applicable. The results are based on merged adjacent-year and yearly models.

Source: Berndt \& Rappaport (2001).

Table 10 Annual price change for ICT-products based on hedonic and matched model price indexes for different time periods and countries

\begin{tabular}{|c|c|c|c|c|c|}
\hline Country & Period & Product & Matched model & Hedonic index & Difference \\
\hline Netherlands & $\begin{array}{c}\text { Jan } 1999-\text { Jan } \\
2002\end{array}$ & PCs & -21.9 & -32.5 & 10.6 \\
\hline Netherlands & $\begin{array}{c}\text { Jan } 1999-\text { Jan } \\
2002\end{array}$ & Notebooks & -20.5 & -25.5 & 5.0 \\
\hline Netherlands & $\begin{array}{c}\text { Jan } 1999-\text { Jan } \\
2002\end{array}$ & Servers & -22.1 & -27.3 & 5.2 \\
\hline France & 2001-I - 2002-II & Computers & -13.7 & -42.1 & 28.4 \\
\hline Japan & 1995-I-1999-I & PCs & -42.7 & -45.1 & 2.4 \\
\hline Japan & 1995-I-1999-I & TVs & -18.8 & -10.4 & -8.4 \\
\hline Australia & $\begin{array}{c}\text { Apr 2000-Dec } \\
2001\end{array}$ & PCs & -32 & -52 & 20.0 \\
\hline USA & 1972-1984 & $\begin{array}{l}\text { Computer } \\
\text { processors }\end{array}$ & -8.5 & -19.5 & 11 \\
\hline USA & 1989-1992 & $\begin{array}{l}\text { Desktop } \\
\text { PCs }\end{array}$ & -19.3 & -31.2 & 11.9 \\
\hline
\end{tabular}

Note: The hedonic price index is based on the dummy variable method for all countries except France where the hedonic imputation method has been used.

Sources: Triplett (2004) and Berndt, Griliches \& Rappaport (1995). 
Figure 1 Producer price index for Sweden 1900-35 (1900=100)

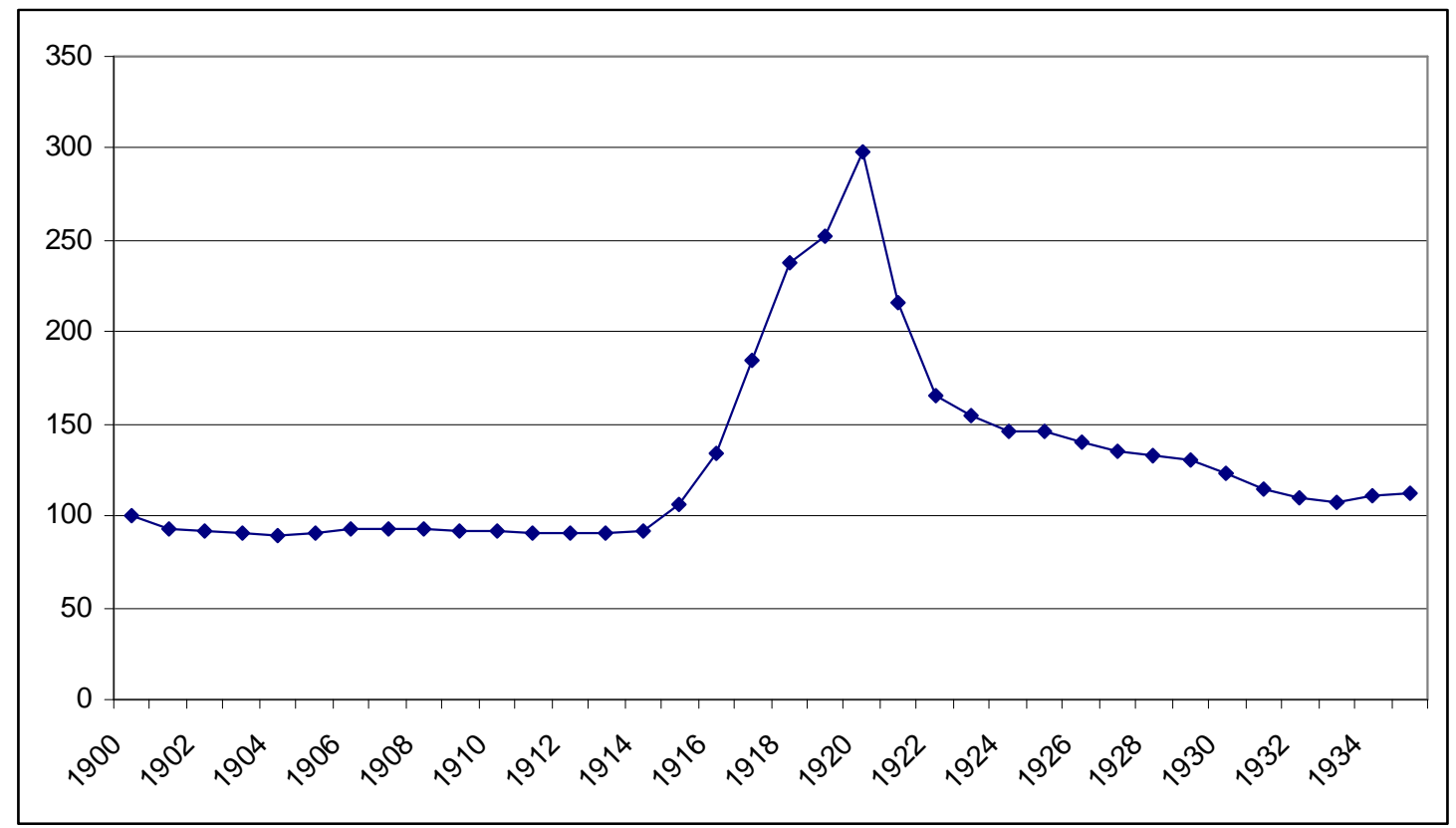

Source: Ljungberg (1990)

Figure 2 Hedonic and matched model price indexes for alternating current slip-ring electric motors 1900-35 in current and PPI-deflated prices $(\mathbf{1 9 0 0}=\mathbf{1 0 0})$

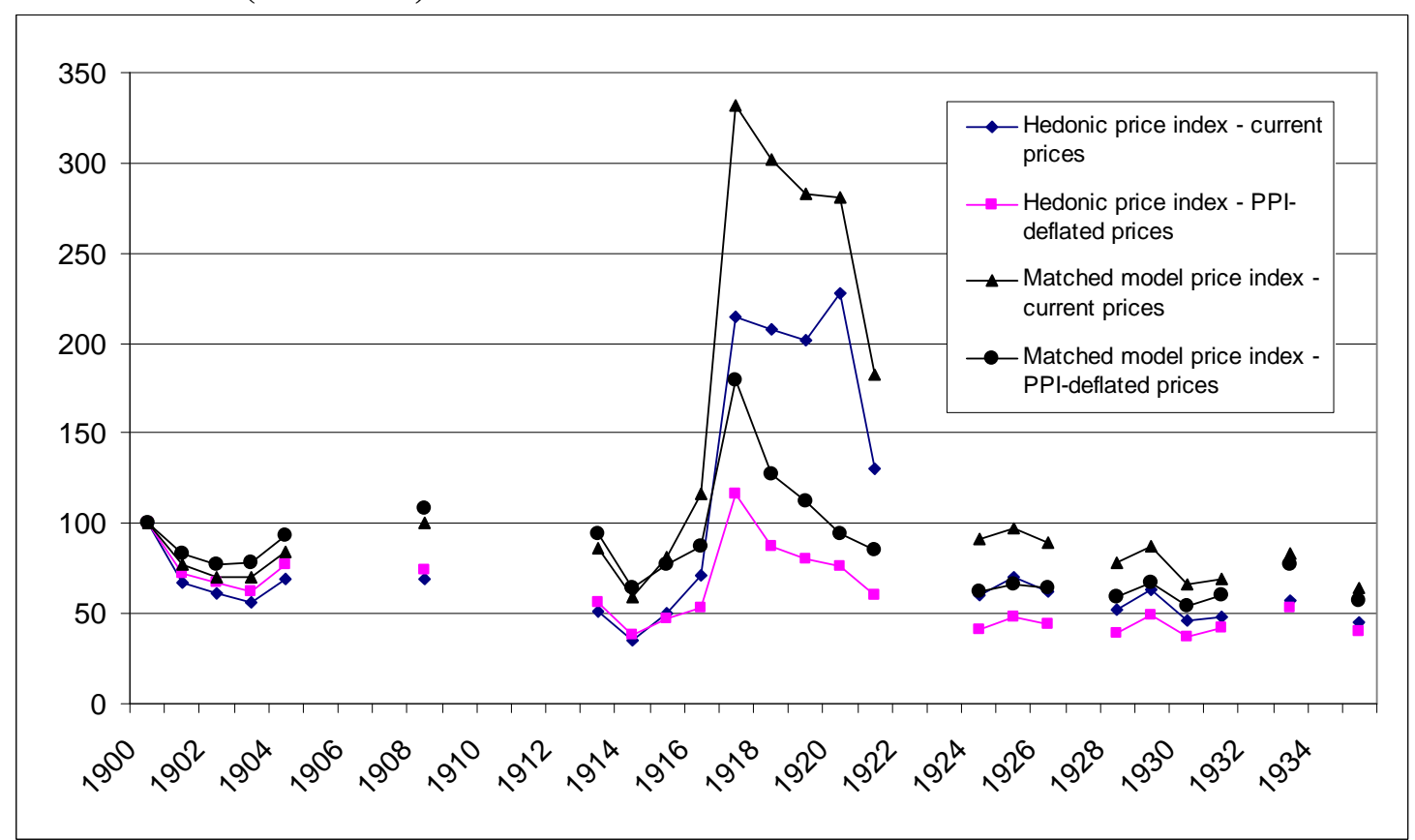

Sources: ASEA (1900-1935), the Swedish Royal Library (1900-1935) and own calculations. 